\title{
Assimilation of trace elements ingested by the mussel Mytilus edulis: effects of algal food abundance
}

\author{
Wen-Xiong Wang ${ }^{1}$, Nicholas S. Fisher ${ }^{1, *}$, Samuel N. Luoma ${ }^{2}$ \\ ${ }^{1}$ Marine Sciences Research Center, State University of New York, Stony Brook, New York 11794-5000, USA \\ ${ }^{2}$ Water Resources Division, MS465, US Geological Survey, 345 Middlefield Road, Menlo Park, California 94025, USA
}

\begin{abstract}
Pulse-chase feeding and multi-labeled radiotracer techniques were employed to measure the assimilation of 6 trace elements $\left({ }^{110 \mathrm{~m}} \mathrm{Ag},{ }^{241} \mathrm{Am},{ }^{109} \mathrm{Cd},{ }^{57} \mathrm{Co},{ }^{75} \mathrm{Se}\right.$ and $\left.{ }^{65} \mathrm{Zn}\right)$ from ingested diatoms in the mussel Mytilus edulis feeding at different rates $\left(0.1,0.49\right.$ and $\left.1.5 \mathrm{mg} \mathrm{dry} \mathrm{wt} \mathrm{h}^{-1}\right)$. Uniformly radiolabeled diatoms Thalassiosira pseudonana were fed to mussels for $0.5 \mathrm{~h}$, and the behavior of the radiotracers in individual mussels was followed for $96 \mathrm{~h}$ in a depuration seawater system. Assimilation efficiency (AE) of each element declined with increasing ingestion rate and increased with gut passage time. The importance of extracellular digestion relative to intracellular digestion increased with ingestion activity, which, when coupled with a decline in AE, suggested that extracellular digestion is less efficient in metal absorption. Zn assimilation was most affected by ingestion rate, suggesting that $\mathrm{AE}$ may play a role in the physiological regulation of this metal in $M$. edulis. In an experiment to simulate the effects of an acidic gut, lowered $\mathrm{pH}$ (5.5) enhanced the release of elements from intact diatom cells, especially at low particle concentration. These results indicate that both feeding components of the mussel (i.e. gut passage time, digestive partitioning) and metal chemistry (i.e. metal release at lowered $\mathrm{pH}$ within the bivalve gut) are responsible for the difference in the assimilation of trace metals at different food quantities observed in mussels.
\end{abstract}

KEY WORDS: Mussels - Assimilation - Bioindicators - Metals · Americium - Cadmium - Cobalt Selenium $\cdot$ Silver $\cdot$ Zinc

\section{INTRODUCTION}

Marine mussels are able to accumulate substantial amounts of trace metals from ambient seawater and have been employed worldwide to monitor contamination in coastal waters (Goldberg et al. 1978, 1983, O'Connor 1992). An important assumption behind this program is that there is a direct relationship between environmental metal contamination and concentrations in the mussel tissues. For suspension-feeding bivalves there are 2 major routes by which a metal can become available to the animal, namely, dissolved uptake and particulate ingestion. Dissolved uptake occurs primarily through the gills and probably does not require energy investment (Carpene \& George 1981). Metal associated with food particles becomes available to bivalves fol-

- Addressee for correspondence.

E-mail:nfisher@ccmail.sunysb.edu lowing the ingestion and absorption of particles within the digestive tracts. Metal uptake from food remains poorly understood. Quantifying the relative importance of dissolved and food sources is essential to the interpretation of data generated by environmental monitoring programs, but this also is poorly understood for most metals of environmental concern and most bioindicator species. We therefore measured the effects of food quantity on the assimilation of 6 trace elements (studied with the radiotracers ${ }^{110 \mathrm{~m}} \mathrm{Ag},{ }^{241} \mathrm{Am},{ }^{109} \mathrm{Cd},{ }^{57} \mathrm{Co},{ }^{75} \mathrm{Se}$ and ${ }^{65} \mathrm{Zn}$ ) in the blue mussel Mytilus edulis. The objectives of this study were: (1) to determine the effects of food quantity on the assimilation efficiency (AE) of ingested trace elements in mussels; (2) to assess the importance of physiological parameters (gut passage time and digestive partitioning) on metal assimilation in mussels; and (3) to explore the significance of metal desorption under different $\mathrm{pH}$ conditions for metal assimilation at different food concentrations. 
According to simple kinetic bioenergetic-based models, metal bioaccumulation is related to metal influxes from both dissolved and particulate sources, and metal efflux from the animal (Thomann 1981, Landrum et al. 1992, Luoma et al. 1992). In these models AE is one of the major parameters determining metal influx from food sources and the relative importance of the particulate vector in the overall metal influx into mussels. Few studies, however, have directly measured AE of trace metals in mussels or studied the processes and factors controlling metal assimilation. Metal assimilation is probably dependent upon many abiotic and biotic conditions. Thus, metal AE should be determined rigorously under different conditions before a general bioaccumulation model can be applied to the field. Food quantity can significantly influence the AE of phytoplankton food in mussels (Thompson \& Bayne 1972, Widdows 1978, Winter 1978). However, metal assimilation from food and the effects of food quantity on metal AE in bivalves are largely unknown.

Digestive processes also influence assimilation. The digestive processes of many bivalves encompass 2 distinct phases, namely extracellular and intracellular digestion (Purchon 1971, Owen 1974, Bayne \& Newell 1983). Extracellular digestion occurs primarily in the stomach once the food materials are ingested, where crystalline styles release extracellular enzymes and degrade whole particles. Intracellular digestion occurs primarily in the digestive diverticula. There, digestive cells phagocytize and digest the fine materials that are channeled from the stomach after extracellular digestion is completed. In pulse-chase studies of assimilation, partitioning of food between these 2 digestive processes has been operationally defined by retention time in the digestive tract (Decho \& Luoma 1991). Partitioning appears to be important in assimilation, although few quantitative studies have been made (Widdows et al. 1979, Decho \& Luoma 1991, 1994). In addition, models of digestion in both deposit and suspension feeders imply that net energy gain can be maximized by optimizing components of the feeding process, including ingestion activity, gut residence time, digestive investment and dietary selection (Taghon et al. 1978, Taghon \& Jumars 1984, Willows 1992). This suggests that an animal's feeding system is flexible in its response to changes in environmental conditions such as food quantity and quality. That flexibility could also influence metal assimilation.

\section{MATERIALS AND METHODS}

Mussels Mytilus edulis of $3.5 \mathrm{~cm}$ shell length were collected from Long Island Sound (LIS), New York,
USA, in July and were maintained at $15^{\circ} \mathrm{C}$ in aerated seawater ( $28 \%$ from LIS) for 1 wk prior to experiments During this acclimation period mussels were fed with cells of the diatom Thalassiosira pseudonana (clone $3 \mathrm{H})$ at a ration above the maintenance requirements (about $2 \%$ of total tissue dry wt $d^{-1}$ ) and the water was changed every $2 \mathrm{~d}$.

Thalassiosira pseudonana was maintained in unialgal, clonal culture in sterile-filtered $(0.2 \mu \mathrm{m}$ Nuclepore), $35 \%$ surface seawater (collected $8 \mathrm{~km}$ off Southampton, New York) enriched with $\mathrm{f} / 2$ nutrients (Guillard \& Ryther 1962). Cells in late log phase were taken from stock cultures and were resuspended off $1 \mu \mathrm{m}$ Nuclepore filters into $1 \mathrm{l}$ Erlenmeyer flasks. Each flask contained $700 \mathrm{ml}$ sterile-filtered $(0.2 \mu \mathrm{m})$ seawater enriched with $f / 2$ levels of $N, P, S i$, and vitamins, but one-tenth ( $\mathrm{f} / 20$ ) levels of trace metals and no addition of $\mathrm{Cu}, \mathrm{Zn}$ or EDTA. The diatom cells in the flasks were then triple labeled with ${ }^{110 \mathrm{~m}} \mathrm{Ag},{ }^{109} \mathrm{Cd}$, and ${ }^{57} \mathrm{Co}$ or ${ }^{241} \mathrm{Am},{ }^{75} \mathrm{Se}$, and ${ }^{65} \mathrm{Zn}$. Radionuclide additions were $37 \mathrm{kBq}\left(10.5 \mathrm{nM}\right.$, in $0.1 \mathrm{~N}$ Ultrex $\mathrm{HNO}_{3}$ ) of ${ }^{110 \mathrm{~m}} \mathrm{Ag}_{;}$ $37 \mathrm{kBq}\left(1.2 \mathrm{nM}\right.$, in $3 \mathrm{~N}$ Ultrex $\left.\mathrm{HNO}_{3}\right)$ of ${ }^{241} \mathrm{Am} ; 74 \mathrm{kBq}$ (34.8 pM, in $0.1 \mathrm{~N}$ Ultrex $\mathrm{HC}$ ) of ${ }^{109} \mathrm{Cd}$; $74 \mathrm{kBq}(4.6 \mathrm{pM}$, in $0.1 \mathrm{~N}$ Ultrex $\mathrm{HCl})$ of ${ }^{57} \mathrm{Co} ; 55.5 \mathrm{kBq}(0.21 \mathrm{nM}$, in distilled water) of ${ }^{75} \mathrm{Se}$ as selenite, and $92.5 \mathrm{kBq}(56.2 \mathrm{pM}$, in 0.1 Ultrex $\mathrm{HCl}$ ) of ${ }^{65} \mathrm{Zn}$. Before the addition of isotopes and their carriers, an appropriate amount of Suprapur $1 \mathrm{~N} \mathrm{NaOH}$ (in $\mu$ l quantities) was added to ensure that the $\mathrm{pH}$ of the water was 8.0 after isotope additions.

The cultures were then incubated on a $14 \mathrm{~h}$ light: $10 \mathrm{~h}$ dark cycle at $15^{\circ} \mathrm{C}$. After $4 \mathrm{~d}$ incubation the cell density increased from $2.0 \times 10^{4}$ cell $\mathrm{ml}^{-1}$ to $3.0 \times 10^{6}$ cell $\mathrm{ml}^{-1}$ (i.e. $>7$ divisions), and the cells were considered to be uniformly radiolabeled. The cells were then resuspended off a $1 \mu \mathrm{m}$ Nuclepore membrane (after 2 washes with filtered seawater) and into $50 \mathrm{ml} \mathrm{unla-}$ beled filtered seawater prior to the pulse-chase feeding experiments described below.

Radiolabeled diatoms were transferred into $500 \mathrm{ml}$ glass-fiber-filtered seawater held in a 11 polypropylene beaker. Three cell rations were prepared: 5, 20, and $70 \times 10^{3}$ cells $\mathrm{ml}^{-1}$ (equivalent to $0.11,0.44$ and

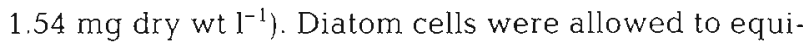
librate for $15 \mathrm{~min}$, and the fraction of metal associated with the particulate phase was then determined by filtering a $10 \mathrm{ml}$ aliquot from each beaker through a $1 \mu \mathrm{m}$ Nuclepore filter, following established procedures (Fisher et al. 1983). Prior to the initiation of pulse-feeding experiments, individual mussels were carefully cleaned of epibiota and fed continuously on unlabeled Thalassiosira pseudonana cells. They were then placed in individual beakers containing radiolabeled diatoms. There were 5 replicate mussels for each food ration treatment. Mussels were allowed to feed on 
radioactive cells for $30 \mathrm{~min}$, during which the water was gently stirred and the cell suspension homogenized every 10 min. Mussels ingested $>95 \%$ of the algal cells available in the water, equivalent to ingestion rates of $0.11,0.44,1.54 \mathrm{mg} \mathrm{h}^{-1}$ for each individual mussel for the low, medium and high food ration group, respectively. This approximately covers the range of food availability during algal bloom and nonbloom conditions in estuaries.

Immediately after feeding on the radiolabeled food, the radioactivity of each mussel was counted (described below). Each mussel was then placed in an individual $240 \mathrm{ml}$ polypropylene chamber containing $170 \mathrm{ml}$ of filtered seawater within a recirculating seawater system (Fig. 1). Water was recycled by pumping from a 201 aquarium through each depuration chamber and back into the aquarium. The flow rate through each depuration chamber was $1.81 \mathrm{~h}^{-1}$.

Each day, diatom cells were separated from a $5 \mathrm{l}$ culture onto a $3 \mu \mathrm{m}$ Nuclepore membrane, then resuspended into filtered seawater $(0.2 \mu \mathrm{m})$. This eliminated the potential effect of EDTA complexation with metals and the effects of algal exudates on the feeding behavior of mussels (Ward \& Targett 1989). Algae were supplied continuously, via a peristaltic pump, from a reservoir culture into 3 recirculating aquaria to ensure that mussels maintained relatively constant feeding activity 10.1, $0.49,1.5 \mathrm{mg} \mathrm{h}^{-1}$, for low, medium and high food ration treatments, respectively) throughout the depuration period.

After $96 \mathrm{~h}$ of depuration, individual mussels were dissected and the radioactivity associated with shells was determined. This activity (generally a very small fraction of the total body activity) was subtracted from the whole body count before the calculation of metal retention in mussel soft tissues.

The radioactivity of each whole mussel was measured periodically (every 3 to $12 \mathrm{~h}$ ) and non-invasively by placing individual mussels inside a large-well $\mathrm{NaI}$ (Tl) gamma detector interfaced to a multi-channel analyzer (Canberra Series 35 plus). Counts were related to standards for each radiotracer at each sample time. Periodically (every 1 to $8 \mathrm{~h}$ ), fecal pellets of mussels were removed from the depuration chamber with a wide-bore pipette and their radioactivity was counted. No attempt was made to separate the pseudofeces from feces at the highest ration group. The gamma emission of ${ }^{110 \mathrm{~m}} \mathrm{Ag}$ was detected at $658 \mathrm{keV}$, of ${ }^{241} \mathrm{Am}$ at $60 \mathrm{keV}$, of ${ }^{109} \mathrm{Cd}$ at $22 \mathrm{keV}$ (the $\mathrm{x}$-rays produced by the daughter product ${ }^{109} \mathrm{Ag}$ ), of ${ }^{57} \mathrm{Co}$ at $122 \mathrm{keV}$, of ${ }^{75} \mathrm{Se}$ at $264 \mathrm{keV}$, and of ${ }^{65} \mathrm{Zn}$ at $1115 \mathrm{keV}$. Counting times were adjusted so that propagated counting errors were generally $<5 \%$, except for some samples whose radioactivity was not significantly above background levels.

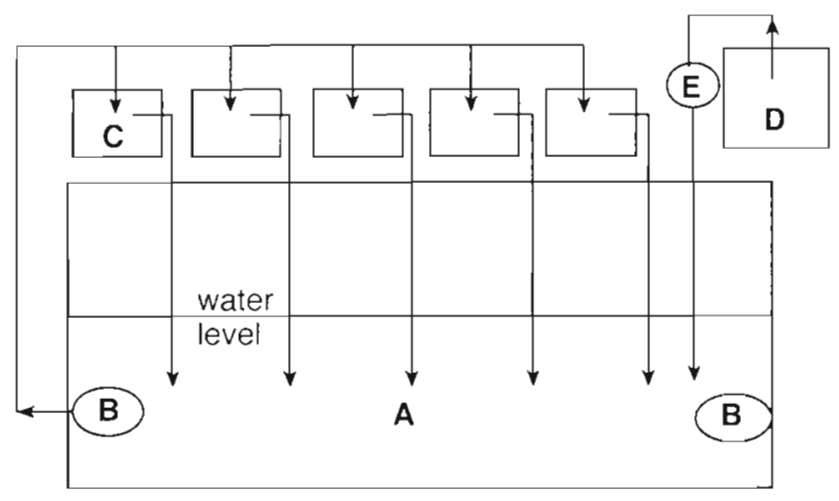

Fig. 1. Experimental aquarium in which mussels were maintained to depurate the labeled food material which was ingested. A: recirculating and aerated seawater; $B$ : recirculating and aerated water pump; C: mussel's chamber; D: food vessel $_{i} E$ : peristaltic pump. Arrows indicate the direction of water flow

Bivalve guts are acidic (Purchon 1971, Owen 1974) and this may strongly affect the desorption, digestion and assimilation of trace metals associated with ingested food particles. Consequently, the release of metals from intact diatom cells at low pH (5.5, a typical gut $\mathrm{pH}$ ) was simulated in microcosm experiments and compared with metal release from cells at $\mathrm{pH} 8.0$ for 3 different cell densities $\left(2.2,11,22 \mathrm{mg} \mathrm{l}^{-1}\right)$. To perform these experiments, Thalassiosira pseudonana cells were inoculated and radiolabeled as described, and log-phase cells were resuspended in $150 \mathrm{ml}$ of $0.2 \mu \mathrm{m}$ filtered seawater. There were 2 replicates for each treatment. Before the resuspension of labeled cells, the $\mathrm{pH}$ (5.5) was lowered by addition of Ultrex $0.1 \mathrm{~N} \mathrm{HCl}$ and monitored throughout the experimental period. Algal cell concentration in each treatment was checked by measuring fluorescence (Brand et al. 1981). Periodically $(0.5,1,2,4,8,16,24 \mathrm{~h})$, an aliquot of $10 \mathrm{ml}$ was filtered onto a $1.0 \mu \mathrm{m}$ Nuclepore membrane and a volume/volume concentration factor (VCF) was calculated for each isotope:

$$
\mathrm{VCF}=M_{\mathrm{p}} / M_{\mathrm{d}}
$$

where $M_{\mathrm{p}}$ is radioactivity $\mu \mathrm{m}^{-3}$ diatom cells, and $M_{\mathrm{d}}$ is radioactivity $\mu \mathrm{m}^{-3}$ dissolved $(<0.2 \mu \mathrm{m})$ in water.

\section{RESULTS}

\section{Patterns of depuration and defecation}

The retention of radiotracers $\left({ }^{110 \mathrm{~m}} \mathrm{Ag},{ }^{241} \mathrm{Am},{ }^{109} \mathrm{Cd}\right.$ ${ }^{57} \mathrm{Co},{ }^{75} \mathrm{Se}$ and ${ }^{65} \mathrm{Zn}$ ) in mussel soft tissues during the $96 \mathrm{~h}$ depuration period is shown in Fig. 2. Three processes contribute to the retention pattern: (1) the 

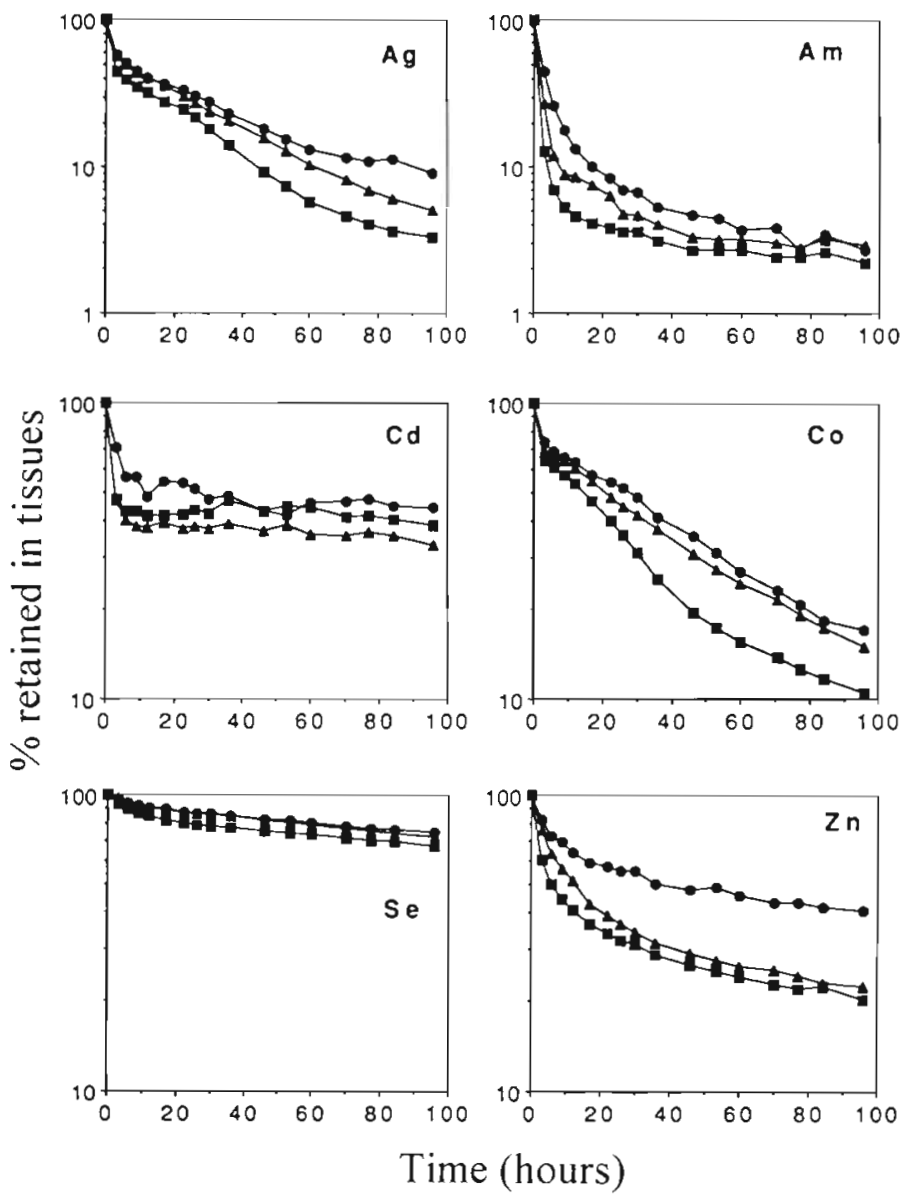

Fig. 2. Mytilus edulis. \% retained of different radiotracers in mussel's soft tissues during 'cold' depuration period. (-) Low ingestion rate $\left(0.1 \mathrm{mg} \mathrm{h}^{-1}\right),(\Delta)$ medium ingestion rate $\left(0.49 \mathrm{mg} \mathrm{h}^{-1}\right)$, ( $\left.\mathbf{\square}\right)$ high ingestion rate $\left(1.5 \mathrm{mg} \mathrm{h}^{-1}\right)$. For clarity, standard deviations are not shown, but they were generally small (see Fig. 4). Note the difference of $y$ scale in each graph

tracer retained is assumed to be assimilated; (2) most of the loss of tracer reflects egestion of unassimilated metal via defecation; (3) physiological loss of assimilated tracer is also possible, but in most cases it is probably a small factor over this short period of time. Loss rates from the largest physiological compartments in marine bivalves are on the order of 1 to $2 \% \mathrm{~d}^{-1}$ (N. S. Fisher, J.-L. Teyssié \& S. W. Fowler unpubl.).

Two elements were almost completely lost from the mussels during the $96 \mathrm{~h}$ depuration (Fig. 2). Less than $10 \%$ of ${ }^{241} \mathrm{Am}$ was retained in soft tissue after $24 \mathrm{~h}$; $96 \%$ was egested after $70 \mathrm{~h}$, in all treatments. Depuration of ${ }^{110 \mathrm{~m}} \mathrm{Ag}$ was slower than ${ }^{241} \mathrm{Am}$, but less than $5 \%$ was retained after $96 \mathrm{~h}$ in the highest food treatment; in no treatment was greater than $12 \%$ of the ${ }^{110 \mathrm{~m}} \mathrm{Ag}$ retained. Because very little ${ }^{241} \mathrm{Am}$ or ${ }^{110 \mathrm{~m}} \mathrm{Ag}$ was assimilated after ingestion of the diatom cells, these elements could be used as tracers of the passage of food materials through the digestive processes. The difference between ${ }^{241} \mathrm{Am}$ and ${ }^{110 \mathrm{~m}} \mathrm{Ag}$ depuration patterns indicates that these elements, which associate with different fractions of the diatom cell (Reinfelder \& Fisher 1991), may follow different digestive pathways.

The activity of fecal pellets was also directly analyzed through time as the pellets were egested. The instantaneous egestion rate $(\mathrm{Bq}$ $\mathrm{h}^{-1}$ ) of unassimilated metal was calculated from the fecal analyses (Fig. 3). Little detectable ${ }^{241} \mathrm{Am}$ activity was observed in feces after $24 \mathrm{~h}$, consistent with rapid and nearly complete depuration. Unlike ${ }^{241} \mathrm{Am}$, a biphasic pattern characterized ${ }^{110 \mathrm{~m}} \mathrm{Ag}$ egestion. A pulse of unassimilated ${ }^{110 \mathrm{~m}} \mathrm{Ag}$ activity was lost in the first $17 \mathrm{~h}$, followed by a second pulse between 17 and $70 \mathrm{~h}$. These results verified that unassimilated metal could be retained for as long as $70 \mathrm{~h}$ in the mussel digestive tract. The end point for the completion of digestion and assimilation was therefore taken as $70 \mathrm{~h}$ in all experiments. Shorter depuration times could overestimate assimilation. Assimilation efficiency (AE) of ingested elements was calculated as the percentage of the radioactivity for each isotope retained by the mussel at $70 \mathrm{~h}$ divided by the amount of radioactivity ingested.

Although there was rapid initial loss of ${ }^{109} \mathrm{Cd}$, ${ }^{57} \mathrm{Co},{ }^{75} \mathrm{Se}$ and ${ }^{65} \mathrm{Zn}$ from mussels, there were moderately high concentrations (>10\% of the initial radioactivity) of these radioisotopes still remaining in the tissues after $70 \mathrm{~h}$. Thus, the pattern of depuration and defecation of these elements reflected a mixture of assimilation, defecation and physiological loss. For example, in all treatments, most unassimilated ${ }^{109} \mathrm{Cd}$ was egested within the first $17 \mathrm{~h}$, after which very little ${ }^{109} \mathrm{Cd}$ appeared in feces or was lost from tissues. This suggested that if ${ }^{109} \mathrm{Cd}$ was retained for longer than $17 \mathrm{~h}$ in the digestive tract, it was assimilated.

Nearly all the ${ }^{75}$ Se was assimilated from the ingested diatom cells, regardless of retention time. Defecation accounted for $<10 \%$ of the ingested ${ }^{75} \mathrm{Se}$. The activity of ${ }^{75}$ Se increased in fecal pellets after $24 \mathrm{~h}$, and was defecated at a relatively constant rate throughout the experiment (up to $\sim 400 \mathrm{~h}$ in other experiments). This was more likely physiological loss and/or slow dissolved excretion, rather than defecation of unassimilated Se. Thus, determination of ${ }^{75} \mathrm{Se}$ AE at $70 \mathrm{~h}$ may underestimate the bioavailability of the element by a small amount.

The pattern of depuration and defecation displayed by ${ }^{65} \mathrm{Zn}$ was intermediate between those of ${ }^{109} \mathrm{Cd}$ and $110 \mathrm{~m} \mathrm{Ag}$ The greatest activity in feces was found during 
Fig. 3. Mytilus edulis. Instantaneous metal egestion rates during the 'cold' depuration period. Results for all 5 individual mussels are presented. ${ }^{110 \mathrm{~m}} \mathrm{Ag}$ data during the initial defecation periods $(<2 \mathrm{~h})$ are not shown (the scale was 2 to 8 times higher than the scales presented in the figures\} to allow the second phase of egestion to be visualized more clearly. Ingestion rates (mg $\mathrm{h}^{-1}$ ): low food: 0.1 ; medium food: 0.49 ; high food: 1.5
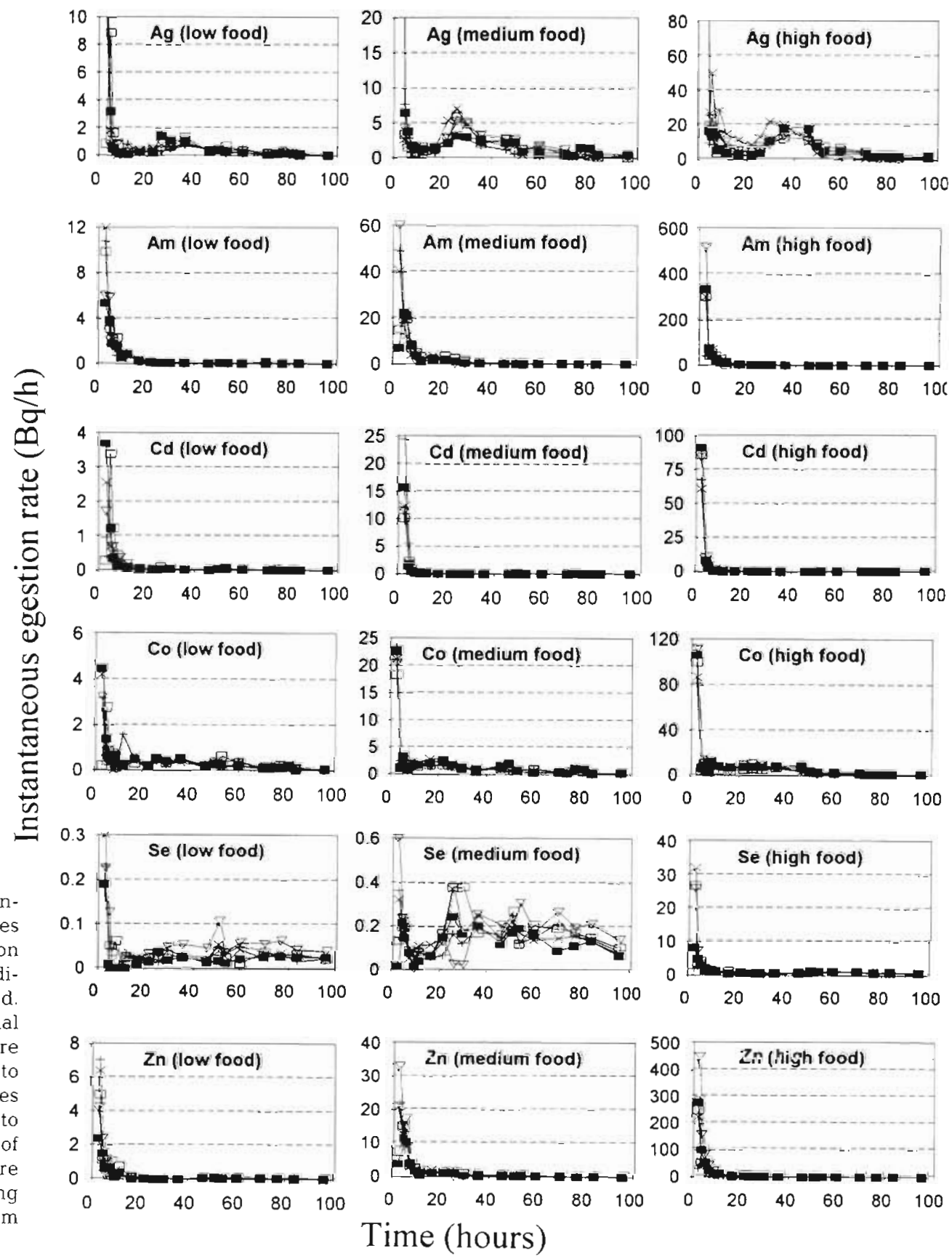

Time (hours) the first $12 \mathrm{~h}$ of depuration. Some unassimilated ${ }^{65} \mathrm{Zn}$ was egested between $12 \mathrm{~h}$ and $70 \mathrm{~h}$, but much of the element retained for longer than $12 \mathrm{~h}$ in the gut was assimilated (only low concentrations of ${ }^{65} \mathrm{Zn}$ were observed in feces after $12 \mathrm{~h}$ ). The assimilation of ${ }^{65} \mathrm{Zn}$ during prolonged digestion was most effective at the lowest food ration. In that treatment, ${ }^{65} \mathrm{Zn}$ followed a depuration pattern most similar to that of ${ }^{109} \mathrm{Cd}$. The depuration rate of ${ }^{57} \mathrm{Co}$ was relatively constant throughout the $96 \mathrm{~h}$.

\section{Assimilation efficiency}

Among the 6 elements, ${ }^{75} \mathrm{Se}$ had the highest $\mathrm{AE}$ (70 to $80 \%$ ), ${ }^{109} \mathrm{Cd}$ and ${ }^{65} \mathrm{Zn}$ had intermediate assimilation ( 20 to $50 \%$ ), followed by ${ }^{57} \mathrm{Co}(15$ to $25 \%)$. As stated above, ${ }^{110 \mathrm{~m}} \mathrm{Ag}$ and ${ }^{241} \mathrm{Am}$ were least available $(2$ to $10 \%$ ). The AEs decreased linearly with increasing ingestion rate and food concentration (Table 1). With the exception of ${ }^{109} \mathrm{Cd}$, there were statistically significant differences ( $p<0.05,1$-way ANOVA) in AEs be- 

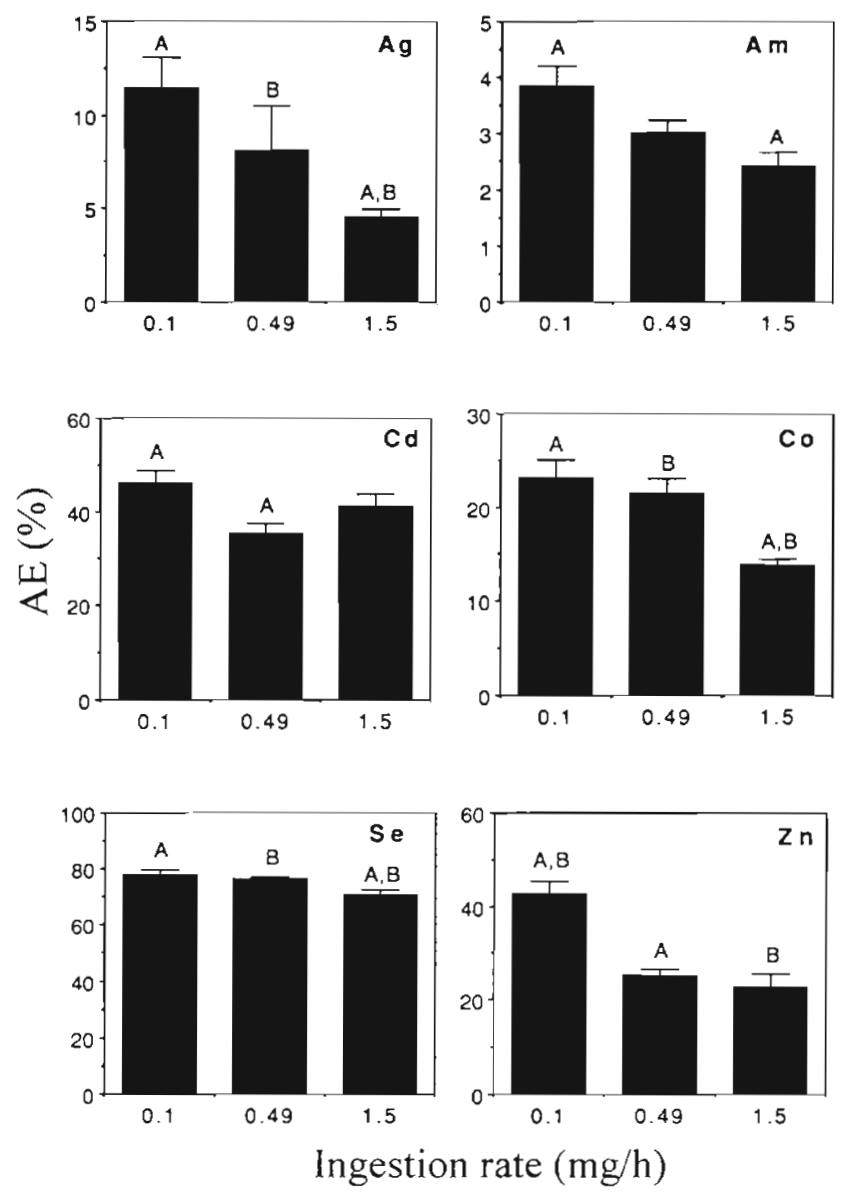

Fig. 4. Mytilus edulis. Calculated assimilation efficiencies (AEs, mean - SE) of trace metals at different ingesting activities of mussels. Both $A$ and $B$ denote that there is a statistically significant difference $(p<0.05,1$-way ANOVA) in AEs between any 2 treatments (ingestion rates)

tween low ration and high ration groups (Fig, 4). There were also significant differences in AEs between medium and high ration groups for ${ }^{110 m} \mathrm{Ag},{ }^{57} \mathrm{Co}$ and ${ }^{75} \mathrm{Se}$. The effect of changing ration on assimilation differed among metals. Zinc was the most influenced by food ration; every $1 \mathrm{mg} \mathrm{h}^{-1}$ difference in ingestion rate

Table 1 Mytilus edulis. Equations describing relationships between metal assimilation efficiency (AE, \%) and ingestion rate of mussels (IR, $\mathrm{mg} \mathrm{h}^{-1}$ )

\begin{tabular}{|cccc|}
\hline Element & Equation & $r$ & $n$ \\
\hline${ }^{110 \mathrm{~m}} \mathrm{Ag}$ & $\mathrm{AE}=11.28-4.64 \times \mathrm{IR}$ & 0.973 & 3 \\
${ }^{24} \mathrm{Am}$ & $\mathrm{AE}=3.74-0.92 \times \mathrm{IR}$ & 0.944 & 3 \\
${ }^{109} \mathrm{Cd}$ & $\mathrm{AE}=42.13-1.71 \times \mathrm{IR}$ & 0.230 & 3 \\
${ }^{57} \mathrm{Co}$ & $\mathrm{AE}=24.33-6.90 \times \mathrm{IR}$ & 0.993 & 3 \\
${ }^{75} \mathrm{Se}$ & $\mathrm{AE}=78.69-5.12 \times \mathrm{IR}$ & 0.999 & 3 \\
${ }^{65} \mathrm{Zn}$ & $\mathrm{AE}=38.72-12.03 \times \mathrm{IR}$ & 0.793 & 3 \\
\hline
\end{tabular}

resulted in a $12 \%$ change in ${ }^{65} \mathrm{Zn}$ assimilation (Table 1). The difference in $\mathrm{AE}$ for ${ }^{57} \mathrm{Co},{ }^{75} \mathrm{Se}$ and ${ }^{110 \mathrm{~m}} \mathrm{Ag}$ was 4.6 to $6.9 \%$ for every $1 \mathrm{mg} \mathrm{h}^{-1}$ change in ingestion rate. There was a notable effect for ${ }^{10 \mathrm{~m}} \mathrm{Ag}$, which was essentially unavailable at high feeding rates but was up to $11 \%$ assimilated (see intercept in Table 1) at the lowest food concentrations. By contrast, food rations had little effect on the AEs of ${ }^{75} \mathrm{Se}$, which were very high at all food concentrations. The effect of food concentration was statistically significant, but only marginally relevant for ${ }^{241} \mathrm{Am}$; the AE for this element was never greater than $4 \%$ at any ration.

\section{Gut passage time and digestive partitioning}

Gut passage time (GPT) was also affected by food ration. GPT was defined from cumulative egestion as the time at which $90 \%$ of the egested metal had been recovered in the feces (assuming there was 100\% recovery at $96 \mathrm{~h}$ ). GPT reflected a combination of assimilation and egestion. The GPT of ${ }^{75} \mathrm{Se}$ was confounded by its very high assimilation at all rations and the detectable dissolved excretion. There was a wide range of GPT among the other elements. For each element, a longer GPT coincided with more efficient assimilation (Fig, 5). The effect of GPT on AE was greatest for ${ }^{109} \mathrm{Cd}$ and ${ }^{65} \mathrm{Zn}$. There was a 3 - to 4 -fold difference in GPT between ingestion rates of 0.1 to $1.5 \mathrm{mg}$ $\mathrm{h}^{-1}$ for these elements.

The differences in GPT among elements at least partly reflected AE differences. For example, ${ }^{241} \mathrm{Am}$ and ${ }^{109} \mathrm{Cd}$ both showed short GPTs, but for different reasons. ${ }^{241} \mathrm{Am}$ was largely unassimilated. It was associated with a cell fraction that was rapidly and almost totally defecated within $24 \mathrm{~h} .{ }^{241}$ Am could therefore be used as an inert tracer of the rapid phase of digestion. The ${ }^{241}$ Am-labeled diatoms passed through the digestive tract twice as fast at high food concentrations as at low food concentrations (Table 2). At all food concentrations, ${ }^{109} \mathrm{Cd}$ was assimilated if it was retained for

Table 2. Mytilus edulis. Gut passage time (GPT, in hours) of 6 trace elements in mussels (mean $\pm \mathrm{SE}$ ) feeding at 3 different rates. For a calculation and discussion of GPT of different elements, see text

\begin{tabular}{|crrr|}
\hline Element & \multicolumn{3}{c|}{ Ingestion rate $\left(\mathrm{mg} \mathrm{h}^{-1}\right)$} \\
& 0.1 & 0.49 & \multicolumn{1}{c|}{1.5} \\
\hline${ }^{110 \mathrm{~m}} \mathrm{Ag}$ & $49.6 \pm 3.8$ & $45.2 \pm 2.7$ & $36.3 \pm 2.0$ \\
${ }^{241} \mathrm{Am}$ & $22.3 \pm 3.7$ & $23.2 \pm 1.9$ & $11.8 \pm 2.7$ \\
${ }^{109} \mathrm{Cd}$ & $19.5 \pm 7.0$ & $6.4 \pm 1.2$ & $4.6 \pm 0.8$ \\
${ }^{57} \mathrm{Co}$ & $64.2 \pm 2.6$ & $59.5 \pm 2.7$ & $43.0 \pm 3.1$ \\
${ }^{65} \mathrm{Zn}$ & $52.2 \pm 4.4$ & $36.3 \pm 2.4$ & $15.3 \pm 4.0$ \\
& & & \\
\end{tabular}



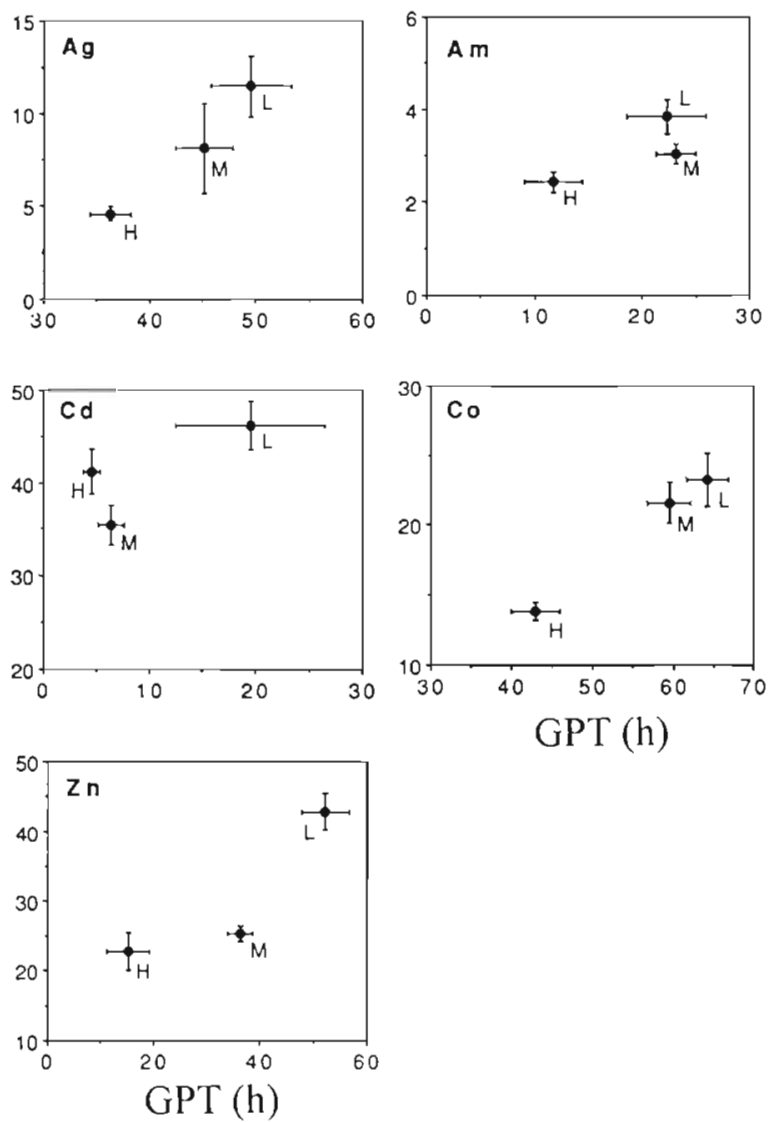

Fig. 5. Mytilus edulis. Metal assimilation efficiencies (AEs) and their relationships with metal gut passage times (GPT) (mean $\pm \mathrm{SE}$ ). For definitions of AE and GPT, see text. L: low ingestion rate $\left(0.1 \mathrm{mg} \mathrm{h}^{-1}\right)$; $\mathrm{M}$ : medium ingestion rate $(0.49 \mathrm{mg}$ $\left.\mathrm{h}^{-1}\right) ; \mathrm{H}$ : high ingestion rate $\left(1.5 \mathrm{mg} \mathrm{h}^{-1}\right)$

long periods in the digestive tract. Thus, at the lowest food ration, any ${ }^{109} \mathrm{Cd}$ retained longer than $19.5 \mathrm{~h}$ was assimilated. At higher food concentrations the GPT declined to $4-6 \mathrm{~h}$. Because the ${ }^{109} \mathrm{Cd} \mathrm{AE}$ also decreased, this verified the ${ }^{241} \mathrm{Am}$ results, i.e. food was pushed through the less efficient phase of digestion faster as the food ration increased.

The change in GPT and AE with food ration was also the result of a higher proportion of food being passed through the most rapid phase of digestion. The phases of digestion were tracked using ${ }^{110 \mathrm{~m}} \mathrm{Ag}$ as a tracer of food passage through the mussel gut, including digestive diverticula (in contrast to ${ }^{241} \mathrm{Am}$, which only undergoes the first phase of digestion), because this radioisotope showed very little retention after $70 \mathrm{~h}$ of depuration. The percentage of food processed by intracellular $(17$ to $70 \mathrm{~h}$ ) digestion was calculated by

$$
\% \text { intracellular }=\frac{A_{\text {feces } 17-70 \mathrm{~h}}}{A_{\text {feces } 0-17 \mathrm{~h}}+A_{\text {feces 17-70h }}} \times 100
$$

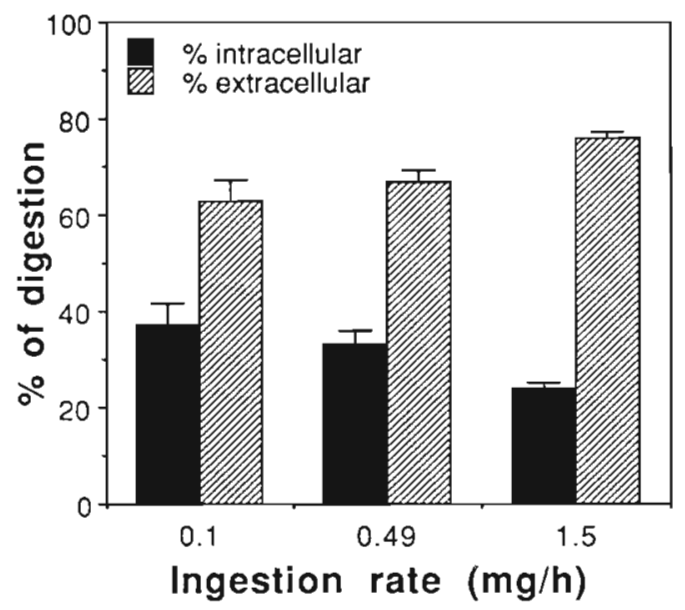

Fig. 6. Mytilus edulis. The proportion of food materials subjected to intracellular and extracellular digestion at different ingestion activities of mussels. Calculations were based on the presumption that ${ }^{110 \mathrm{~m}} \mathrm{Ag}$ is an inert tracer of food particles $($ mean $+\mathrm{SE})$

where $A_{\text {feces } 0-17 \mathrm{~h}}$ is the cumulative ${ }^{110 \mathrm{~m}} \mathrm{Ag}$ activity measured in feces between 0 and $17 \mathrm{~h}$ and $A_{\text {feces } 17-70 \mathrm{~h}}$ is the cumulative ${ }^{110 \mathrm{~m}} \mathrm{Ag}$ activity measured in feces between 17 and $70 \mathrm{~h}$. The \% of food processed by extracellular digestion was

$$
\% \text { extracellular }=100-(\% \text { intracellular })
$$

A greater proportion of the food was processed via the shorter, extracellular digestion pathway as food availability increased (Fig. 6). Because extracellular digestion was inefficient in absorbing metals, this led to the decreases in AEs noted at the higher food rations. The depuration rate during the slower, intracellular digestion process (i.e. after 17 h) did not vary significantly with food availability for ${ }^{109} \mathrm{Cd},{ }^{57} \mathrm{Co}$ and ${ }^{75} \mathrm{Se}$ (Table 3 ). Food availability therefore had no influence on intracellular assimilation of these elements. On the other hand, ${ }^{110 \mathrm{~m}} \mathrm{Ag}$ and ${ }^{65} \mathrm{Zn}$ were depurated faster between 17 and $70 \mathrm{~h}$ with increased food availability (Table 3 ). This was also evident from the depuration pattern (Fig. 2). At the lower food rations, a greater proportion of these elements was assimilated during intracellular digestion. Because very little $(<8 \%$ at $24 \mathrm{~h})$ of the ingested ${ }^{241} \mathrm{Am}$ was retained by the mussels, the depuration rate constants for this radioisotope are only marginally relevant.

\section{Release of metals from intact diatom cells under lowered $\mathrm{pH}$ conditions}

The behavior of 3 elements $\left({ }^{110 \mathrm{~m}} \mathrm{Ag},{ }^{241} \mathrm{Am}\right.$ and $\left.{ }^{75} \mathrm{Se}\right)$, each having a different characteristic cellular distribu- 
Table 3. Mytilus edulis. Depuration rate constants $\left(k, \% \mathrm{~h}^{-1}\right.$, calculated from linear regressions of $\ln \%$ retained over time) of 6 trace elements between 17 and $70 \mathrm{~h}$ at 3 different ingestion rates $\left(0.1,0.49\right.$ and $\left.1.5 \mathrm{mg} \mathrm{h}^{-1}\right)($ mean $\pm \mathrm{SE}, \mathrm{n}=5)$. $A$ and $B$ denote statistically significant differences $(p<0.05,1$-way ANOVA) between any 2 treatments (ingestion rates). These calculations assume firstorder depuration patterns for trace elements in mussels

\begin{tabular}{|c|c|c|c|c|c|c|}
\hline \multirow[t]{2}{*}{ Element } & \multicolumn{3}{|c|}{$k\left(\% \mathrm{~h}^{-1}\right)$} & \multicolumn{3}{|c|}{$\mathrm{r}$} \\
\hline & 0.1 & 0.49 & 1.5 & 0.1 & 0.49 & 1.5 \\
\hline${ }^{110 \mathrm{~m}} \mathrm{Ag}$ & $1.89 \pm 0.14^{\mathrm{A} B \mathrm{~B}}$ & $2.60 \pm 0.12^{\mathrm{A}}$ & $3.01 \pm 0.15^{3}$ & 0.96 & 0.99 & 0.97 \\
\hline${ }^{241} \mathrm{Am}$ & $1.62 \pm 0.14^{\mathrm{A}, \mathrm{B}}$ & $1.02 \pm 0.09^{\mathrm{A}}$ & $0.67 \pm 0.13^{B}$ & 0.88 & 0.82 & 0.88 \\
\hline${ }^{109} \mathrm{Cd}$ & $0.21 \pm 0.03$ & $0.16 \pm 0.08$ & $0.10 \pm 0.07$ & 0.66 & 0.72 & 0.61 \\
\hline${ }^{57} \mathrm{Co}$ & $1.69 \pm 0.12$ & $1.64 \pm 0.05$ & $1.90 \pm 0.08$ & 0.99 & 0.99 & 0.97 \\
\hline${ }^{75} \mathrm{Se}$ & $0.23 \pm 0.03$ & $0.27 \pm 0.01$ & $0.24 \pm 0.02$ & 0.96 & 0.99 & 0.97 \\
\hline${ }^{65} \mathrm{Zn}$ & $0.50 \pm 0.06^{A . B}$ & $0.78 \pm 0.04^{\mathrm{A}}$ & $0.76 \pm 0.09^{B}$ & 0.94 & 0.96 & 0.97 \\
\hline
\end{tabular}

(phytoplankton and seston particles) in marine bivalves, using an 'ash ratio' method (which measures organic matter assimilation; Conover 1966) or a radiotracer method $\left({ }^{14} \mathrm{C}\right.$ ) (Hawkins et al. 1983, Borchardt 1985). Using a monospecific phytoplankton (Tetraselmis suecica) diet for mussels, Thompson \& Bayne $(1972,1974)$ showed that $\mathrm{AE}$ of carbon from food declined $27 \%$ for every $1 \mathrm{mg} \mathrm{l}^{-1}$ change in ration (for a maximum of $90 \%$ ) with increasing food concentration. Other studies using a diatom (Phaeodactylum tricornutum) or a prymnesiophyte (Isochrysis galbana) also indicated that $\mathrm{AE}$ was inversely

tion in diatom cells, is presented in Fig. 7. Reinfelder \& Fisher (1991) found that $>95 \%$ of ${ }^{241} \mathrm{Am}$ is associated with Thalassiosira pseudonana cell walls and plasmalemmae, whereas $>90 \%$ of ${ }^{75} \mathrm{Se}$ is distributed in the cytoplasm. ${ }^{110 \mathrm{~m}} \mathrm{Ag}$ is intermediate between these 2 end members (ca 15\% in cytoplasm). Although more total radioactivity was lost into the dissolved phase from cells resuspended at lower cell densities than at high cell densities, the volume-volume concentration factor (VCF) for all elements decreased with increasing particle concentration and remained relatively constant over the $24 h$ experimental period. Lowered $\mathrm{pH}$ reduced the VCFs of ${ }^{110 \mathrm{~m}} \mathrm{Ag}$ and ${ }^{241} \mathrm{Am}$ but this effect tended to be smaller with increasing particle loads (Fig. 7). Lowered $\mathrm{pH}$ did not have an appreciable effect on the release of ${ }^{75} \mathrm{Se}$ from intact diatom cells, presumably because this element was primarily in the cytoplasm and less available for desorption or exchange.

\section{DISCUSSION}

Our results demonstrate a statistically significant influence of food quantity on AEs of different trace elements. Metal assimilation can be described as a negative function of a mussel's ingestion rate, but the slope of this function depends upon the metal and is lower than that described for organic matter assimilation. This means that assimilation of ingested metal is less sensitive than assimilation of organic matter to changes in food quantity, across a range of ingestion rates that a mussel might employ in nature. Metal assimilation changes from $<1 \%$ (for ${ }^{241} \mathrm{Am}$ ) to $12 \%$ (for ${ }^{65} \mathrm{Zn}$ ) for every $1 \mathrm{mg} \mathrm{h}^{-1}$ change in ingestion rate, while carbon assimilation varies from 13 to $27 \%$ (see below; Thompson \& Bayne 1972, Bayne et al. 1989). Earlier studies have measured the AEs of food particles related to food quantity (Widdows 1978, Borchardt 1983). When mussels were acclimated to a mixture of
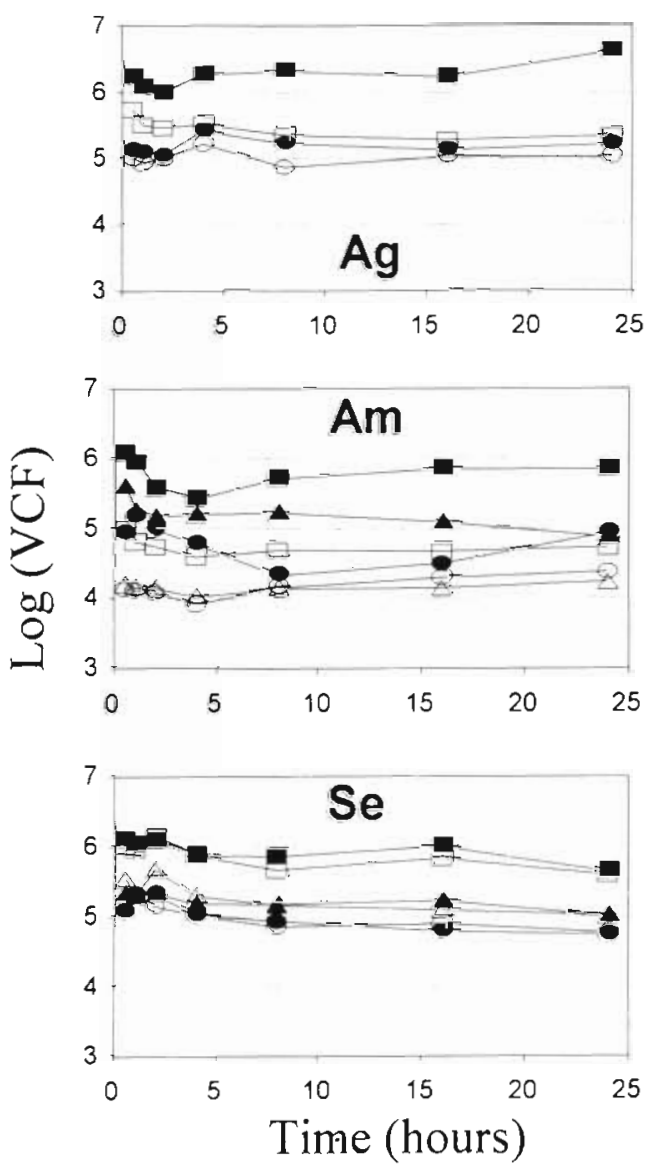

Fig. 7. Thalassiosira pseudonana. Metal concentration factors (VCFs) in intact diatom cells at lowered $\mathrm{pH}$ (5.5) and at differ-

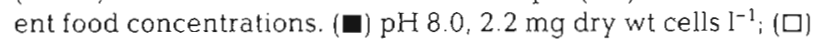
pH 5.5, $2.2 \mathrm{mg}$ dry wt cells $1^{-1} ;(\mathbf{\Lambda}) \mathrm{pH} 8.0,11 \mathrm{mg}$ dry wt cells

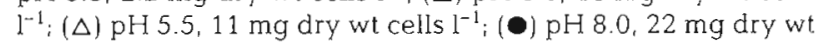
cells $\mathrm{l}^{-1}$; (O) pH 5.5, $22 \mathrm{mg}$ dry wt cells $\mathrm{l}^{-1}$ 
algal cells and surficial silt sediments for $2 \mathrm{wk}, \mathrm{AE}$ was less affected by food quantity, changing from $63 \%$ at an ingestion rate of $0.99 \mathrm{mg}$ particulate organic matter $\mathrm{h}^{-1}$ to $50 \%$ at $1.97 \mathrm{mg} \mathrm{h}^{-1}$ (Bayne et al. 1989).

Few studies have directly examined the influence of food density on the assimilation of trace metals. Bjerregaard et al. (1985) found that mussels retained more ${ }^{241} \mathrm{Am}$ (about $15 \%$ ) when maintained on a low food ration (Thalassiosira pseudonana $3 \mathrm{H}$ cells, $10^{4}$ cells $\left.\mathrm{ml}^{-1}\right)$ than on a higher food ration $\left(2 \%\right.$ for $5 \times 10^{4}$ cells $\mathrm{ml}^{-1}$ ). Borchardt (1983) observed a larger effect than seen in our studies. He found 63 and $28 \% \mathrm{Cd} \mathrm{AE}$ in mussels at ingestion rates of 0.026 and $0.2 \mathrm{mg} \mathrm{h}^{-1}$, respectively, of Isochrysis galbana. In these studies, mussels were fed with radiolabeled food particles for a few days to weeks. The calculated retention efficiency would underestimate AE. The pulse-chase feeding technique avoids many of the problems associated with long-term experiments (metal recycling, previous contamination history, physiological turnover and behavioral anomaly; Luoma et al. 1992), and thus represents a more realistic measure of $\mathrm{AE}$.

The proportion of food materials that is sent to the digestive gland for intensive digestion is critical in determining food assimilation (Van Weel 1961, Thompson \& Bayne 1972, 1974, Widdows et al. 1979, Bayne \& Newell 1983). Widdows et al. (1979), for example, suggested that, at low food density $<0.25 \mathrm{mg}$ $\mathrm{l}^{-1}$ ), all ingested materials are transported to the digestive gland and the unassimilated materials are egested as glandular feces. With increasing food concentration the digestive gland is unable to digest and assimilate all the materials that are entering the stomach. Consequently the undigested materials bypass the digestive gland and are transported through the intestinal gut and defecated as intestinal feces. These 2 types of feces are readily discernible in bivalves (Van Weel 1961, Thompson \& Bayne 1972). In our experiments we also observed the distinct features of feces produced by mussels at different food quantities. Mussels maintained at a low food level $\left(0.1 \mathrm{mg} \mathrm{h}^{-1}\right)$ produced darkcolored feces, whereas with increasing ingestion activity the feces became lighter and browner in color, implying that intestinal feces become dominant as ingestion increased.

Decho \& Luoma (1991) observed biphasic ${ }^{51} \mathrm{Cr}$ fecal egestion in 2 clam species, Macoma balthica and Potamorcobula amurensis, after the clams were pulse-fed with ${ }^{51} \mathrm{Cr}$-impregnated glass beads or bacteria. The first phase was characterized as extracellular digestion occurring primarily within the stomach. The second phase was characterized as intracellular digestion associated with the digestive diverticula (Purchon 1971 , Owen 1974). Furthermore, the proportion of extracellular and intracellular digestion appears to be impor- tant in the overall assimilation of ${ }^{51} \mathrm{Cr}$. For example, ${ }^{51} \mathrm{Cr}$ was assimilated only by intracellular digestion, presumably because cells in the digestive gland are efficient at phagocytizing fine particles generated by extracellular digestion (Decho \& Luoma 1991, 1994).

Biphasic metal defecation was also evident in the pulse-chase experiments with Mytilus edulis. Using $110 \mathrm{~m}$ Ag as an inert tracer, a generic model of metal egestion would include 2 different phases, namely extracellular ( 0 to $17 \mathrm{~h}$ ) and intracellular (17 to $70 \mathrm{~h}$ ) digestion. The pattern of egestion varied with different metals, depending upon metal chemistry, cellular distribution in Thalassiosira pseudonana, and the pattern of assimilation by the mussels. For example, $>87 \%$ of ${ }^{241} \mathrm{Am}$ was defecated after extracellular digestion. Reinfelder \& Fisher $(1991,1994)$ showed that $>95 \%$ of ${ }^{241} \mathrm{Am}$ is bound to the cell surface of $T$. pseudonana. Thus, the cell fraction that sequesters ${ }^{241} \mathrm{Am}$ does not seem to pass through intracellular digestion in the mussel, perhaps contributing to the very low assimilation of this element by the mussel. In contrast, 30 to $40 \%$ of ${ }^{241} \mathrm{Am}$ is assimilated from $T$. pseudonana by the clam Macoma balthica (Luoma et al. 1992). In this animal, about $40 \%$ of the ${ }^{241} \mathrm{Am}$ from $T$. pseudonana is passed through intracellular digestion.

Fisher \& Reinfelder (1991) and Reinfelder \& Fisher (1991, 1994) also showed that ${ }^{75}$ Se is mainly associated with algal cytoplasm. Once the algal cell is lysed in the digestive tract, Se is probably rapidly assimilated, whatever the phase of digestion. Thus, Se availability to mussels appears to follow the hypothesis of Reinfelder \& Fisher $(1991,1994)$. They suggested that, at least for copepods and planktonic bivalve larvae (whose digestion is primarily extracellular), assimilation of elements is related to the elemental distribution in algal cytoplasm. Selenium was the most available of the elements because its cytoplasmic distribution was the highest.

Adult bivalves are capable of both extracellular and intracellular digestion. Interaction of the 2 processes could enhance assimilation of some elements. For example, the absence of ${ }^{109} \mathrm{Cd}$ in the second phase of egestion appeared to represent very efficient intracellular assimilation of this element. This element can be tightly bound to low molecular weight proteins (e.g. metallothioneins; Köhler \& Riisgård 1982, Bebianno \& Langston 1991) that may be assimilated only during intracellular digestion. Assimilation of $\mathrm{Zn}$ was more affected by increased ration than other elements, partly because intracellular digestion was affected. The best evidence illustrating the importance of intracellular digestion in the mussels, however, was the observation of reduced $\mathrm{AE}$ as the percentage of particles subjected to extracellular digestion increased with increased food availability. 
The digestion kinetics described above satisfactorily explain Ag and Co assimilation, but an alternative explanation cannot be excluded. A proportion of these metals could become loosely bound to the gut lining within the first $17 \mathrm{~h}$, from which they are slowly released or excreted during cycles of cell formation and breakdown in the digestive diverticula between 17 and $70 \mathrm{~h}$. With this explanation, the proportion of total egested Ag recovered in feces from 17 to $70 \mathrm{~h}$ decreases inversely with ingestion rate because, as a consequence of shorter GPT, less Ag is released from ingested phytoplankton (an explanation consistent with the above). This alternative explanation would also necessitate that some Ag crosses the gut lining at lower ingestion rates but not at higher rates. The mechanism for that is unclear.

GPT also affects metal assimilation at different food concentrations. This is consistent with many studies showing that AE of food materials increases with GPT. Longer retention of ingested food within the digestive tract allows for more efficient digestion and absorption (Willows 1992). Previous empirical measurements and optimal digestive models predict that AE increases with GPT to a maximum beyond which AE remains relatively constant (Bayne et al. 1987. Willows 1992). Mussels therefore exhibit great digestive plasticity which allows them to change the amount/activity of digestive enzymes and gut volume (involving both ingestion rate and gut retention time) in response to changes in food quantity/quality (Bayne et al. 1989). Previous estimations of GPT for food particles are gen-

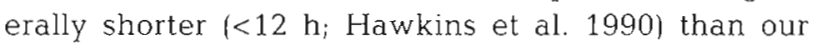
data indicate. In assuming that mussels complete their digestion of food materials within $1 \mathrm{~d}$, these earlier studies may have overestimated assimilation.

Many studies indicate that $\mathrm{Zn}$ levels in mussel tissues are regulated and not highly responsive to $\mathrm{Zn}$ concentrations in seawater. Thus mussels are not a good indicator of $\mathrm{Zn}$ contamination in the aquatic environment (Amiard et al. 1986, Amiard-Triquet et al. 1986, Phillips 1990). Under steady-state conditions, bioaccumulation can be described by a simple mathematical equation, assuming that metal influx rates are directly proportional to metal concentrations in seawater and food particles (Landrum et al. 1992, Luoma et al. 1992):

$$
C=\left[I_{\mathrm{d} 1 \mathrm{~s}}+\left(\mathrm{AE} \times \mathrm{IR} \times C_{\mathrm{p}}\right)\right] / k_{\mathrm{e}}
$$

where $C$ is metal concentration in mussel tissue $\left(\mu \mathrm{g} \mathrm{g}^{-1}\right), I_{\text {dis }}$ is metal influx rate from dissolved sources $\left(\mu \mathrm{g} \mathrm{g}^{-1} \mathrm{~d}^{-1}\right)$, AE is metal assimilation efficiency (\%), IR is ingestion rate of mussels ( $\mathrm{mg} \mathrm{g}^{-1} \mathrm{~d}^{-1}$ ), $C_{\mathrm{p}}$ is metal concentration of ingested particles $\left(\mu \mathrm{mg}^{-1}\right)$, and $k_{\mathrm{e}}$ is the metal efflux rate constant $\left(\mathrm{d}^{-1}\right)$.

From this equation several potential sources may explain $\mathrm{Zn}$ regulation in mussels, including metal influx rate from the dissolved phase, metal assimilation efficiency and metal efflux rate. Our results demonstrate that there is a 1.5 -fold difference in ${ }^{65} \mathrm{Zn} \mathrm{AE}$ at ingestion rates between 0.1 and $1.5 \mathrm{mg} \mathrm{h}^{-1}$. Musseis are therefore able to vary their assimilation of $\mathrm{Zn}$ from food particles in response to different environmental conditions such as food quantity. A significant decrease in $\mathrm{Zn} A \mathrm{AE}$ when food particles are abundant may balance $\mathrm{Zn}$ intake from ingested particles. Thus, AE may be an important physiological factor responsible for $\mathrm{Zn}$ regulation observed in many studies. The influx rate of $\mathrm{Zn}$ from the dissolved phase is directly proportional to the $\mathrm{Zn}$ concentration in ambient seawater, indicating that dissolved uptake is primarily a passive process without active regulation (W-X. Wang, N. S. Fisher \& S. N. Luoma unpubl.). Furthermore, bioaccumulation modeling using Eq. (3) suggests that the predominant route by which $\mathrm{Zn}$ is accumulated in mussel tissue is via particulate ingestion: the contribution of dissolved uptake only accounts for ca $20 \%$ of total $\mathrm{Zn}$ uptake (Wang \& Fisher unpubl.). The importance of metal efflux in $\mathrm{Zn}$ regulation in mussels is still unstudied. Bryan (1984) showed that the whole body $\mathrm{Zn}$ levels in the polychaete Neresis diversicolor are kept constant by excretion of excess metal. In oysters the loss rate constant $\left(k_{\mathrm{e}}\right)$ for $\mathrm{Zn}$ is related to the uptake rate constant and to the steady-state concentration factor of $\mathrm{Zn}$ (Cutshall 1974). Such a mechanism in metal regulation is also common in decapod crustaceans (Depledge \& Rainbow 1990).

The desorption experiments illustrate why it is problematic to predict metal bioavailability from simple chemical conditions in the digestive tract, such as lowered $\mathrm{pH}$ or particle concentrations. Chemical conditions during digestion are flexible and complex. Such conditions are undoubtedly different in extracellular and intracellular digestion (Decho \& Luoma 1991). Molluscs also modify the chemistry of particles as they process them for digestion. For example, even before digestion begins, mussels envelope food particles in mucus strings. An endoscopic study showed that these strings are produced, even at low food concentrations, in the ventral groove, where they are carried to the labial palps for sorting and digestion (Ward et al. 1993). The ultimate bioavailable form of metals must be soluble, either in water or solubilized within the digestive tract (Langston \& Spence 1995). Desorption at lowered $\mathrm{pH}$ within the mussel gut could enhance solubilization, but it is not the only process that removes metal from food particles. For example, ${ }^{75} \mathrm{Se}$ was not released at $\mathrm{pH}$ 5.5, probably because Se speciates as an anion in seawater (Cutter \& Bruland 1984) and, once in the cytoplasm of Thalassiosira pseudonana cells, it forms organic selenides (Fisher \& Reinfelder 1991). A more accurate simulation of digestion would require includ- 
ing enzymes or other chemicals that lyse whole phytoplankton cells.

Although response to lowered $\mathrm{pH}$ does not simulate digestion, experiments can be informative about processes that contribute to assimilation, especially for particle-reactive or surface-bound elements such as ${ }^{110 \mathrm{~m}} \mathrm{Ag}$ or ${ }^{241} \mathrm{Am}$. For example, our measurements indicate that metals desorb from phytoplankton cells within $30 \mathrm{~min}$ after cells are transferred to seawater with a pH of 5.5, as noted earlier (Fisher \& Teyssié 1986). Processes other than desorption are presumably responsible for the relationship of metal assimilation and gut retention on time scales of hours. Greater desorption also occurs at lower particle concentrations and could play a role in the increased assimilation of ${ }^{110 \mathrm{~m}} \mathrm{Ag},{ }^{65} \mathrm{Zn}$ or ${ }^{57} \mathrm{Co}$ at lower ingestion rates. However, the desorption experiments predict substantial changes in the availability of ${ }^{241}$ Am that are not observed in the mussels.

In summary, this study demonstrates how digestive processes and metal chemistry interact to determine metal assimilation when ingestion rates of algal food differ. Elements occurring almost entirely within the cytoplasm of the algal cell (e.g. Se) are efficiently assimilated, and food availability is proportionately unimportant. Elements strongly bound to fraction(s) of the algal cell that are not passed through intracellular digestion (e.g. ${ }^{241} \mathrm{Am}$ ) are of very low bioavailability, whatever the availability of food. Many elements ( $\mathrm{Ag}$, $\mathrm{Cd}, \mathrm{Co}, \mathrm{Zn}$ ) lie between these 2 extremes in their chemical behavior, and for them food availability has the greatest effect. A higher AE is observed at lower food availability because of longer gut residence time, a higher proportion of intracellular digestion, and perhaps a higher release rate under acidic conditions in the gut. Assimilation of these elements and carbon assimilation are both affected by food availabililty. Thus, relationships between metal and carbon assimilation are expected (Borchardt 1985). However, metal asssimilation appears to be less influenced by variability in food than does carbon assimilation, at least under the experimental conditions employed here. Comparisons between metals and carbon of the mechanistic causes of the influence of food availability have not yet been reported. In any case, the variabililty in AE occurring across the range of ingestion rates typical of mussels in nature is sufficient, at least for some trace elements, that it should be incorporated into bioaccumulation models before such models are applied in the field.

Acknowledgements. We thank J. Reinfelder and anonymous reviewers for many helpful comments. This research was supported by grants from the U.S. EPA (R81947201), the New York Sea Grant Institute (NA90AADSG078), and the National Association of Photographic Manufacturers. This is MSRC Contribution No. 991

\section{LITERATURE CITED}

Amiard JC, Amiard-Triquet C, Berthet B, Metayer C (1986) Contribution to the ecotoxicological study of cadmium, lead, copper and zinc in the mussel, Mytilus edulis. I. Field study. Mar Biol 90:425-431

Amiard-Triquet C, Berthet B, Metayer C, Amiard JC (1986) Contribution to the ecotoxicological study of cadmium, lead, copper and zinc in the mussel, Mytilus edulis. II. Experimental study. Mar Biol 92:7-13

Bayne BL, Hawkins AJS, Navarro E (1987) Feeding and digestion by the mussel Mytilus edulis L. (Bivalvia: Mollusca) in mixtures of silt and algal cells at low concentration. J exp mar Biol Ecol 111:1-22

Bayne BL, Hawkins AJS, Navarro E, Iglesias IP (1989) Effects of seston concentration on feeding, digestion and growth in the mussel Mytilus edulis. Mar Ecol Prog Ser 55 $47-54$

Bayne BL, Newell RC (1983) Physiological energetics of marine molluscs. In: Saleuddin ASM, Wilbur KM (eds) The Mollusca, Vol 4. Academic Press, London, p 407-515

Bebianno MJ, Langston WJ (1991) Metallothionein induction in Mytilus edulis exposed to cadmium. Mar Biol 108:91-96

Bjerregaard P, Topçuoğlu S, Fisher NS, Fowler SW (1985) Biokinetics of americium and plutonium in the mussel Mytilus edulis. Mar Ecol Prog Ser 21:99-111

Borchardt $T$ (1983) Influence of food quantity on the kinetics of cadmium uptake and loss via food and seawater in Mytilus edulis. Mar Biol 76:67-76

Borchardt T (1985) Relationship between carbon and cadmium uptake in Mytilus edulis. Mar Bıol 85:233-244

Brand LE, Guillard RRL, Murphy LS (1981) A method for the rapid and precise determination of acclimated phytoplankton reproduction rates. J Plankton Res 3:193-202

Bryan GW (1984) Pollution due to heavy metals and their compounds. In: Kinne $O($ ed) Marine ecology, Vol 5, Part 3. John Wiley \& Sons, New York, p 1289-1431

Carpene $\mathrm{E}_{1}$ George SG (1981) Absorption of cadmium by gills of Mytilus edulis. Mol Physiol 1:23-34

Conover RJ (1966) Assimilation of organic matter by zooplankton. Limnol Oceanogr 11:338- 354

Cutshall $N$ (1974) Turnover of zinc-65 in oysters. Health Phys 26:327-331

Cutter GA, Bruland KW (1984) The marine biogeochemistry of selenium: a re-evaluation. Limnol Oceanogr 29: $1179-1192$

Decho AW. Luoma SN (1991) Time-courses in the retention of food material in the bivalves Potamocorbula amurensis and Macoma balthica: significance to the absorption of carbon and chromium. Mar Ecol Prog Ser 78:303-314

Decho AW, Luoma SN (1994) Humic and fulvic acid: sink or source in the availability of metals to the marine bivalves Macoma balthica and Potamocorbula amurensis? Mar Ecol Prog Ser 108:133-145

Depledge MH, Rainbow PS (1990) Models of regulation and accumulation of trace metals in marine invertebrates. Comp Biochem Physiol 97C:1-7

Fisher NS, Bjerregaard P, Fowler SW (1983) Interactions of marine plankton with transuranic elements. 1. Biokinetics of neptunium, plutonium, americium, and californium in phytoplankton. Limnol Oceanogr 28:432-447

Fisher NS, Reinfelder JR (1991) Assimilation of selenium in the marine copepod Acartia tonsa studied with a radiotracer ratio method. Mar Ecol Prog Ser 70:157-164

Fisher NS, Teyssié JL (1986) Influence of food composition on the biokinetics and tissue distribution of zinc and americium in mussels. Mar Ecol Prog Ser 28:197-207 
Goldberg ED, Bowen VT, Farrington JW, Harvey G, Martin JH, Parker PL, Risebrough RW, Robertson W, Schneider E, Gamble E (1978) The mussel watch. Environ Cons 5: $101-125$

Goldberg ED, Koide M, Hodge V, Flegal AR, Martin J (1983) U.S. mussel watch: $1977-1978$ results on trace metals and radionuclides. Estuar coast Shelf Sci 16:69-93

Guillard RRL, Ryther JH (1962) Studies of marine planktonic diatoms. 1. Cyclotella nana Hustedt, and Detonula confervacea (Cleve) Gran. Can J Microbiol 8:229-239

Hawkins AJS, Bayne BL, Clarke KR (1983) Co-ordinated rhythms of digestion, absorption and excretion in Mytilus edulis (Bivalvia: Mollusca). Mar Biol 74:41-48

Hawkins AJS, Navarro E, Iglesias JIP (1990) Comparative allometries of gut content, gut passage time and metabolic faecal loss in Mytilus edulis and Cerastoderma edule. Mar Biol 105:197-204

Köhler K, Riisgård HU (1982) Formation of metallothioneins in relation to accumulation of cadmium in the common mussel Mytilus edulis. Mar Biol 66:53-58

Landrum PF, Lee H, Lydy MJ (1992) Toxicokinetics in aquatic systems: model comparisons and use in hazard assessment. Environ Toxicol Chem 11:1709-1725

Langston WJ, Spence SK (1995) Biological factors involved in metal concentrations observed in aquatic organisms. In: Tessier A, Turner DR (eds) Metal speciation and bioavailability in aquatic systems. John Wiley \& Sons, New York

Luoma SN, Johns C, Fisher NS, Steinberg NA, Oremland RS, Reinfelder JR (1992) Determination of selenium bioavailability to a benthic bivalve from particulate and solute pathways. Environ Sci Technol 26:485-491

O'Connor TP (1992) Recent trends in coastal environmental quality: results from the first five years of NOAA mussel watch project. US Dept Commerce, NOAA, Washington

Owen G (1974) Feeding and digestion in the bivalvia. Adv Comp Physiol Biochem 5:1-35

Phillips DJH (1990) Use of macroalgal and invertebrates as monitors of metal levels in estuaries and coastal waters. In: Furness RW, Rainbow PS (eds) Heavy metals in the marine environment. CRC Press, Boca Raton, p 82-99

Purchon RD (1971) Digestion in filter feeding bivalves: a new concept. Proc Malacol Soc Lond 39:253-262

This article was submitted to the editor
Reinfelder JR, Fisher NS (1991) The assimilation of elements ingested by marine copepods. Science 251:794-796

Reinfelder JR, Fisher NS (1994) The assimilation of elements ingested by marine planktonic bivalve larvae. Limnol Oceanogr 39:12-20

Taghon GL, Jumars PA (1984) Variable ingestion rate and its role in optimal foraging behavior of marine deposit-feeders. Ecology 65:549-558

Taghon GL, Self RFL, Jumars PA (1978) Predicting particle selection by deposit-feeders: a model and prediction. Limnol Oceanogr 23:752-759

Thomann RV (1981) Equilibrium model of fate of microcontaminants in diverse aquatic food chains. Can J Fish Aquat Sci 38:280-296

Thompson RJ, Bayne BL (1972) Active metabolism associated with feeding in the mussel Mytilus edulis. J exp mar Biol Ecol 9:111-124

Thompson RJ, Bayne BL (1974) Some relationships between growth, metabolism and food on the mussel Mytilus edulis. Mar Biol 27:317-326

Van Weel PB (1961) The comparative physiology of digestion in molluscs. Am Zool 1:245-252

Ward JE, MacDonald BA, Thompson RJ, Benninger PG (1993) Mechanisms of suspension feeding in bivalves: resolution of current controversies by means of endoscopy. Limnol Oceanogr 38:265-272

Ward JE, Targett NM (1989) Influence of marine microalgal metabolites on the feeding behavior of the blue mussel Mytilus edulis. Mar Biol 101:313-321

Widdows J (1978) Combined effects of body size, food concentration and season on the physiology of Mytilus edulis J mar biol Ass UK 58:109-124

Widdows J, Fieth P, Worrall CM (1979) Relationships between seston, available food and feeding activity in the common mussel Mytilus edulis. Mar Biol 50:195-207

Willows RI (1992) Optimal digestive investment: a model for filter feeders experiencing variable diets. Limnol Oceanogr 37:829-847

Winter JE (1978) A review on the knowledge of suspensionfeeding in lamellibranchiate bivalves, with special reference to artificial aquaculture systems. Aquaculture 13: $1-33$

Manuscript first received: February 22, 1995

Revised version accepted: June 12, 1995 